\title{
Finite Deformation Behavior of Vulcanized Rubbers and \\ Examination of Mooney-Rivlin Plot Method by \\ the Data from Biaxial Extension Experiment
}

by

Sueo KawaBATA

(Department of Polymer Chemistry, Kyoto University, Kyoto, Kyoto 606)

\section{加硫ゴムの大変形挙動の研究 \\ - Mooney-Rivlin プロットの再検討を中心として一}

川端季雄*

(原稿受理：[979年 4 月28日)

\section{1. は じめに}

ゴムの弾性に関して, 分子論的な研究は古く1930年代から 1940 年代にかけて集中的に行われている. Meyer ${ }^{1)}$, Guth と Mark2), $\mathrm{Kuhn}^{3)}$, James ${ }^{4)}$, Treloar ${ }^{5)}$, Flory ${ }^{6}$ などにより分子鎖の運動に基 づ弾性の概念がこの時代に確立した．これらの内容については, 今更ここで紹介するまでもなく, 多くの書物や文献によって紹介 されていると扣りである. 一方, これとは別に今世紀に入って現 象論的な大变形弾性理論の基礎が応用数学の一分野で急速に固め

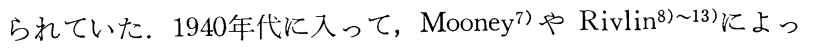
てこれら数学理諭が其体的に大変形解析に応用され始め, 特に Rivlinはゴムといら大変形可能な面白い物質に, この理論の適用 の場を見付け, 大変形理論を更に具体的に組み立てて完成させた のであるが，その功績は大きいと思われる，ただし，Rivlin自身 の興味は, ゴムという物質の物質特性の解明にあったと言うより は, むしろ数学理諭の応用にあったよ5に, 筆者には感じられる. しかしながら，いずれにせよゴムの変形や力学的性質に関する 現象論的な方面からの研究は, Rivlinやその共同研究者であり, 実験家であるSaunders, Thomasなどによって開始され ${ }^{12), 13), ~ コ ゙ ~}$ ムの変形特性の扱い方や, 数学的に見いだされていたゴムの未検 討の性質などについて，理諭を背景とする測定によって研究され たのであって，更にそれらの研究はその後ゴムを研究する高分子 物性の研究者へと引き継がれていくことになる。

1940年代には，はじめに述べたように，分子論からのアプロー

* 京都大学工学部高分子化学教室 京都市左京区吉田本町
チとしての古典ゴム弾性理論と，Rivlin らの純現象理論または 数学理諭としての大変形弾性理論とが並行して進展し, その後, 両者の微妙なからみ合いの下に今日に至っていると言える. 本稿 では，いわばそのからみ合いの一つを述べようと思らが，それは Mooney-Rivlin プロットとよばれる有名なひずみエネルギー密度 関数の一つの決定法を巡ってである。よく知られるように，この 方法は今日までゴム弾性研究の主要な手段の一つとして多く用い られてきた方法である。しかし，最近ゴム弾性に関して新しい 2 軸伸長の観測から，この決定法の再検討が必要であることが明ら かになってきたことについて，この辺の事情を中心に述べようと 思了.

\section{2. 大変形弾性理論の概要}

まず, 現象論の側からの大変形弾性理論を, 特に本稿での説明 に必要な部分に絞って要約して括く. 弾性固体が未変形の自然状 態から外力によって変形を受けるとき, 外部からこの変形のため になされた仕事が弾性体内部の弾性ひずみによって貯えられる弾 性エネルギーをひずみエネルギー (Strain energy) と呼ぶ.この ひずみエネルギーは, 弾性固体が均等に变形していない場合や, 不均質の場合には一般にはその固体内の部分によってこのエネル ギーの強さが異なるが，いま固体内の任意の点 $\mathrm{P}$ 含む小さな領 域に含まれるひずみエネルギーを，その領域の単位体積当たりの 值で表し, 更にその領域の体積を無限に小さくすることにより, その極限值として点 $\mathrm{P} に$ 括けるひずみエネルギーの“強さ”が表 される。これをひずみェネルギー密度 (Strain energy density) 
と呼んでいる。すなわち, 固体内のすべての点のひずみエネルギ 一密度がこのよ5に定義される。 ただし, 上述の単位体積を未変 形時に拈けるその領域の単位体積にとる場合もある. 以下では, この後者の定義を用いることにする.

ひずみエネルギー密度をWで表すことにし，いま点 $\mathrm{P} に$ 打ける 変形状態, 寸なわち具体的には変形テンソルと, 同じくその点の 応力状態, すなわち応力テンソルが与えられると, その点のWは 決をる。

すなわち，次のようにも表現できる，点Pに括けるひずみテン ソルが与えられ，更にその変形によってもたらされるWがわかる と, その点の応カテンソルが計算できる. この関係を記述するの が弾性理論であるが，この変形テンソルとWとの関係は物質特性 として与えられねばならない関係である. 大変形弾性理論では変 形の大きさに制限を設けていない，それらの変形に対してのWが わかっている限り, 変形と応力とは数学的に構成方程式によって, 固体が連続体である限り 1 対 1 の対応が付けられる. 微小変形弾 性理論のよ5に, 物質特性值が定数で表されるとい5単純さがな い代わりに，大変形理論では変形が微小 (Infinitesimal) でなけ ればならないという制限から解放されるので，これから得られる 利点は大さく, 特にゴムのような物質の物質特性を問題にする研 究では, その物質特性を正しく把握するためにも, この大変形理 論は必要と思われる。 大変形理論は, 微小変形理論 (Infinitesimal deformation theory)に対して, 有限变形理論(Finite deformation theory）とも呼ばれるのは，無限小の制約を超えた理論とい5意 味からである。

前述のよ5に，ひずみエネルギ一密度は固体内の応力計算に用 いるために定義されたものであるが，同時にとれには物質固有の 特性が関与している。したがって，物質の特性值としてのその関 数形に興味を持つ場合には, 前述したようなエネルギー密度の概 念は必ずしも必要でなく, 変形時の物質のエネルギー保有特性を 表す特性值としてひずみェネルギー密度を扱ってもよい.すなわ ち，均質な物質に均等な変形を与えたときの固体内のひずみエネ ルギー密度は均等であって, その固体が貯える全ひずみエネルギ 一をその固体の変形前の体積で除した值に等しい，すなわち，変 形によって生じるひずみエネルギーを, 単位体積当たりの量に換 算して表した值と定義して，これを物質特性值として考えるので あるが，本稿でもこのような概念でひずみエネルギ一密度を考光， 同じくWでそれを表すことにする.

以上からわかるように，Wは変形テンソルの関数であり，その 関数形が物質特性を与えるのであるが, このためWをひずみエネ ルギー密度関数とも呼んでいる. その関数形の表現について, $W$ はスカラー量であるから, 変形テンソル $C_{\mathrm{KL}}(\mathrm{K}, \mathrm{L}=1,2,3)-$ ここではGreen の変形テンソルを考えている—をその変数とす ることは困難である. Rivlin らも行ったよ5に，Wを $C_{\mathrm{KL}}$ のス カラー表示とも言える, テンソル $C_{\mathrm{KL}}$ の 3 つの不変量 $I_{i}(i=1$, $2,3)$ を変数として表すのが適当であろう。すなわち, 式(1)の上5 に表す。

$$
W=W\left(I_{1}, I_{2}, I_{3}\right)
$$

応力とひずみの関係について，いま変形の主軸方向に座標軸を 選ぶことによって，一般性を失うことなくそれを簡単に記述する ことができる. 主軸 $X_{i}(i=1,2,3)$ に沿5 3 つの伸長比 $\lambda_{i}(i=$
$1,2,3)$ に対するそれぞれの方向の主応力 $\sigma_{i}(i=1,2,3)$ の関係は 後述する式(3)のようになるが，この座標系での $\lambda_{i}$ を用いて $I_{i}$ は 次式で表される.

$$
\begin{aligned}
& I_{1}=\lambda_{1}{ }^{2}+\lambda_{2}{ }^{2}+\lambda_{3}{ }^{2} \\
& I_{2}=\lambda_{1}{ }^{2} \lambda_{2}{ }^{2}+\lambda_{2}{ }^{2} \lambda_{3}{ }^{2}+\lambda_{3}{ }^{2} \lambda_{1}{ }^{2} \\
& I_{3}=\lambda_{1}{ }^{2} \lambda_{2}{ }^{2} \lambda_{3}{ }^{2}
\end{aligned}
$$

これら $I_{i}$ に対してのWが決まると， $\sigma_{i}$ は次式で求まる14),20)

$$
\begin{gathered}
\sigma_{i}=2 \lambda_{i}\left[\frac{\partial W}{\partial I_{1}}+\left(\lambda_{j}{ }^{2}+\lambda_{k}{ }^{2}\right) \frac{\partial W}{\partial I_{2}}+\lambda_{j}{ }^{2} \lambda_{k}{ }^{2} \frac{\partial W}{\partial I_{3}}\right] \\
(i, j, k=1,2,3 ; i \neq j \neq k)
\end{gathered}
$$

ただし, 応力 $\sigma_{i}$ は $X_{i}$ 軸方向の面に作用する変形前の単位面積 当たりで定義された応力で，いわゆる工業応力 (Engineering stress) である. これに対し, 変形時の面積で定義される応力を 真応力 (Truestress) と呼び，これを $t_{i}$ で表すと，

$$
t_{i}=\frac{\sigma_{i}}{\lambda_{j} \lambda_{k}}
$$

として換算される。

以上は 3 軸変形を含む一般の変形に 対する応力ーひずみ関係を 与えるが，式(3)が示すように直接には $W$ の 3 つ偏微分関数がこ れに必要である。もちろん, 式(1)が確定していると直ちにこの 3 つの関数（やはり一般には $I_{1}, I_{2}, I_{3}$ の関数である）は微分によ って求まる。

加硫ゴムでは，その体積を変化させるには大きなエネルギーを 必要とすることは知られている。例えば，主軸のうちの 2 つの軸 方向の応力がゼロでなく，他の一方向がゼ口のよ5な变形を 2 軸 変形と言うが, この変形では固体の体積はほとんど変わらない。 このような体積不変の性質を非圧縮性と言うが，加硫ゴムがこれ に近い。この場合,

$$
\lambda_{1} \lambda_{2} \lambda_{3}=1
$$

が保有されるので，これと式(3)とから非圧縮性体の 2 軸変形時の 応力とひずみの関係が導かれる.

$$
\begin{aligned}
& \sigma_{1}=\frac{2}{\lambda_{1}}\left[\lambda_{1}{ }^{2}-\frac{1}{\left(\lambda_{1} \lambda_{2}\right)^{2}}\right]\left[\frac{\partial W}{\partial I_{1}}+\lambda_{2}{ }^{2} \frac{\partial W}{\partial I_{2}}\right] \\
& \sigma_{2}=\frac{2}{\lambda_{2}}\left[\lambda_{2}{ }^{2}-\frac{1}{\left(\lambda_{1} \lambda_{2}\right)^{2}}\right]\left[\frac{\partial W}{\partial I_{1}}+\lambda_{1}{ }^{2} \frac{\partial W}{\partial I_{2}}\right] \\
& \sigma_{3}=0
\end{aligned}
$$

この場合の変形テンソルの不変量は,

$$
\left.\begin{array}{ll}
I_{1}=\lambda_{1}{ }^{2}+\lambda_{2}{ }^{2}+\frac{1}{\left(\lambda_{1} \lambda_{2}\right)^{2}} & \text { (i) } \\
I_{2}=\left(\lambda_{1} \lambda_{2}\right)^{2}+\frac{1}{\lambda_{1}{ }^{2}}+\frac{1}{\lambda_{2}{ }^{2}} & \text { (ii) } \\
I_{3}=1 & \text { (iii) }
\end{array}\right\}
$$

となる. ゴム弾性の研究に执いて, 体積不変の条件下での弾性举 動が报われるのは， 3 軸変形を考えない限り， $I_{3}=1$ が変形に関 係なくほぼ成り立つことからと，現実には 1 軸と 2 軸の変形が多 いから，まずこうした変形に対する弾性の研究が始められたこと によるものと思われる.なかでも 1 軸変形が多く研究の対象とさ れるのは，これは最も容易に実現できる変形椂式であるためであ ろう。しかし，この 1 軸変形は体積不変の変形様式の一部にすぎ ないことを注意する必要がある.

$\partial W / \partial I_{1}, \partial W / \partial I_{2}$ 等は前述の上5に物質特性関数であって 
$\left(\partial W / \partial I_{3}\right.$ は非圧縮性の場合は消去できる), 分子論などから誘導 されるか，または実測によって求められるしかない，古典ゴム弾 性論からは, $W$ として次式が導かれる15)。

$$
W=\frac{1}{2} N k T\left(I_{1}-3\right)
$$

$N$, 有効網目数; $k$, ボルッマン定数; $T$, 絶対温度である.こ れから直ちに次式の偏微分形が導かれる.

$$
\left.\begin{array}{ll}
\frac{\partial W}{\partial I_{1}}=\frac{1}{2} N k T \quad \text { （一定温度下では定数）（i ) } \\
\frac{\partial W}{\partial I_{2}}=0 & \text { (ii) }
\end{array}\right\}
$$

一方, 実測から求めるには，ただ一つ，2 軸伸長下での応力, 伸長 比関係を測定する方法がある。 $\lambda_{1}, \lambda_{2}$ を与え，それに刘応する $\sigma_{1}$, $\sigma_{2}$ を測定し, これらを式(6) (i), (ii) に代入して未知数 $\partial W / \partial I_{1}$, $\partial W / \partial I_{2}$ を代数的に解く計算で求めればよい。そして，さまざま な組み合わせの $\lambda_{1}, \lambda_{2}$ に対して同じ操作を繰り返し， $\partial W / \partial I_{i}$ の 各関数形を決めることがでさる．ただし，この方法では $W$ 直接 測定とはならないが，Wはその偏微分形の積分から推定される. しかし，実際には応力ーひずみ関係の記述には式(3)や式(6)の上5 に, この偏微分形が直接に関与するので, これが精密に求まる方 が有り難いわけで，この形で物質特性を評価する場合が多い，

\section{Rivlin の 2 軸伸長実験から得られたデータ}

$W$ 関数の決定には, 前述のよ5に 2 軸伸長の実験が必要である が，1943年に Treloar ${ }^{5)}$ が,こうしたW関数の測定, と言うよりも ゴム弾性理論の結諭である式(9)の検証の目的であるが，2 軸伸長 実験を行っているのは，本質を追求する点で卓見であったと思 5 . その後, RivlinはSaundersとともに $\partial W / \partial I_{i}$ の決定にこのTreloar の方法を応用して, 式(6)により既に述べた方法でそれら関数形を
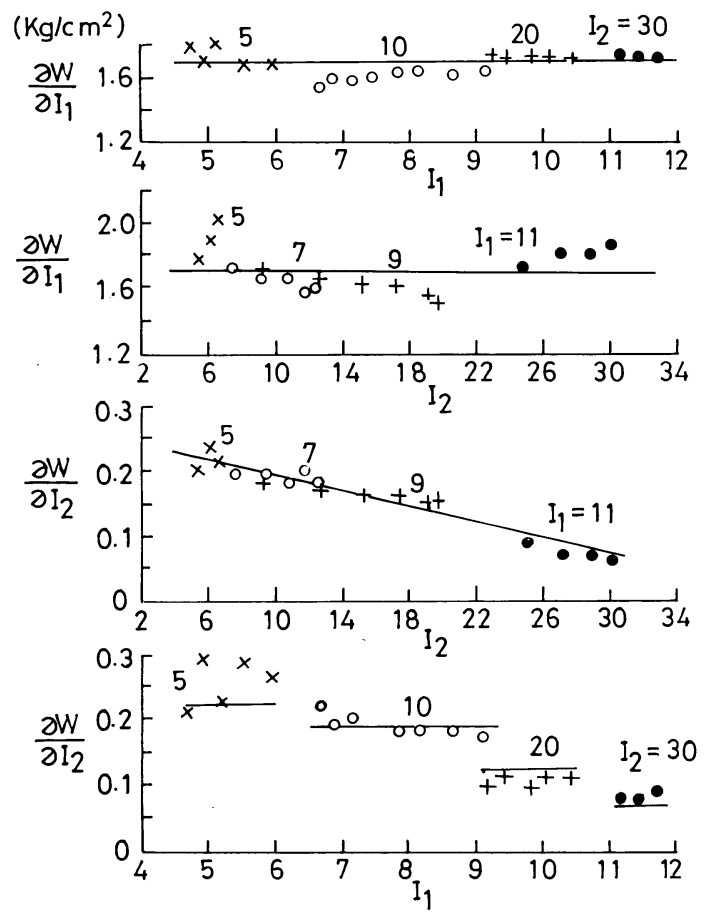

Fig. $1 \partial W / \partial I_{1}$ and $\partial W / \partial I_{2}$ measured by Rivlin and Saunders ${ }^{12)}$ in 1951 for natural rubber vulcanizate.
求めている ${ }^{12)}$. Fig. 1 は加硫天然ゴムについての Rivlin らのデ 一タでよく引用される有名なるのであるが，このデータからわか る重要な点は，(1) $\partial W / \partial I_{2}$ は古典 ゴム弾性論の結論の式(9)に反 してゼロでない值を持つこと，(2) $\partial W / \partial I_{1}$ はほほ注定数とみなせ ること,の 2 点である. この実験に先立って, RivlinはWの関数 形の決定のために，次のような高次展開式を用意していた，体積 不変の変形に刘しては， $C_{i j}$ を定数係数として，

$$
\begin{aligned}
W= & \sum_{i=0}^{\infty} \sum_{j=0}^{\infty} C_{i j}\left(I_{1}-3\right)^{i}\left(I_{2}-3\right)^{j} \\
= & C_{00}+C_{10}\left(I_{1}-3\right)+C_{01}\left(I_{2}-3\right)+C_{11}\left(I_{1}-3\right)\left(I_{2}-3\right) \\
& +C_{20}\left(I_{1}-3\right)^{2}+\cdots
\end{aligned}
$$

であるが，ここで，未変形時 $\left(I_{1}=I_{2}=3\right)$ に扔いて，W=0でな ければならないことから，(I-3) の形が生まれているが，また $C_{00}=0$ でもなければならない，他の定数係数はもちろん実測で 決定される。 この展開式の最も簡単な $I_{1}, I_{2}$ の 1 次項のみをとっ た形式は， $C_{10} \equiv C_{1}, C_{01} \equiv C_{2}$ と置いて，

$$
W=C_{1}\left(I_{1}-3\right)+C_{2}\left(I_{2}-3\right)
$$

である。これは Mooney 式と呼ばれているが7)，これより直ちに

$$
\frac{\partial W}{\partial I_{1}}=C_{1} \quad \text { (i ), } \quad \frac{\partial W}{\partial I_{2}}=C_{2} \quad \text { (ii) }
$$

が導ける．Fig. 1 のデータからあまり大きな変形域でない限り， データのばらつきから $\partial W / \partial I_{2}$ もやや無理をすれば定数とも置け るので, 式(11)の実用性がクローズアップされたのである。ちなみ に $C_{2}=0$ の場合を, Rivlin は Neo-Hookean 弾性と呼んだが, この性質が古典ゴム弾性論で導かれている. したがって, このこ とが， $C_{2}$ は果たして分子論的にいか導かれるかという疑問へ とつながったのである、いずれにせよ $C_{1}$ が注潘定数であるとい らこの実験事実は，次述べる Mooney-Rivlin プロットによる ひずみエネルギー密度関数の決定法を生むことになる.

\section{Mooney-Rivlin プロット}

式(6)から，例えば $X_{1}$ 軸方向への 1 軸伸長の場合の応力と伸長 比の関係を導くと, 次式が得られる。

$$
\begin{aligned}
& \sigma_{1}=2\left(\lambda_{1}-\frac{1}{\lambda_{1}^{2}}\right)\left(\frac{\partial W}{\partial I_{1}}+\frac{1}{\lambda_{1}} \frac{\partial W}{\partial I_{2}}\right) \\
& \sigma_{2}=\sigma_{3}=0
\end{aligned}
$$

ただし，この場合は

$$
I_{1}=\lambda_{1}{ }^{2}+\frac{2}{\lambda_{1}} \quad \text { (i ) }, \quad I_{2}=2 \lambda_{1}+\frac{1}{\lambda_{1}{ }^{2}}
$$

式(13)k $\partial W / \partial I_{1}=C_{1}, \partial W / \partial I_{2}=C_{2}$ と置いてこれらを代入し, 更 に形を少し変えると次式が得られる.

$$
\frac{\sigma_{1}}{2\left(\lambda_{1}-\frac{1}{\lambda_{1}^{2}}\right)}=C_{1}+\frac{1}{\lambda_{1}} C_{2}
$$

すなわち， 1 軸伸長実験で得られる $\sigma_{1}$ と $\lambda_{1}$ との関係から，各 $\lambda_{1}$ の場合について左辺を計算し，1/ $\lambda_{1}$ を横軸にとってプロット すれば, 式(15)は直線が得られることを示し, かつ, 縦軸との交点か ら $C_{1}$ を，また傾斜から $C_{2}$ を決定できる．仮に直線でない場合 も， $C_{1}$ を定数と仮定すれば， $C_{2}$ はその接線から変形に依存する 值としてて求まることになる，この方法の正当性は少なくともFig. 1 のデータが示しているが，簡単な 1 軸伸長実験で $\partial W / \partial I_{1}, \partial W$ 
$/ \partial I_{2}$ の値が決定できるという点で，この方法は Rivlin によって 提出されて以来広く受け入机られ，今日もな扮用いられている方 法である。この方法が特に高分子物性の研密者によって広く応用 されたのには, 実験の容易さもさることながら, 何よりも古典ゴ ム弾性論から導かれる関係, すなわちこのプロットでは横軸に平 行な水平線が得られる関係に対して傾斜が観測されるとい5, 分 子論の不足分を明快に示す点に理由があるよ5に思う。このあた りに分子論と現象論が微妙にからんでいるのである。このプロッ トが Mooney-Rivlin プロットと呼ばれているが，以下で M-R プ ロットと略して示すことにする.

ここでもう一つ断って和く必要があるのは, 非ガウス鎖の理論 である. 非ガウス鎖の効果は逆ランジュバン関数形で示されるよ 5に，応力とひずみ関係に打ける大さな伸長域での応力の立ち上 がり現象を説明する。 これはまた M-R プロットに打いても，大 変形域に扣いて直線を立ち上がらせる效果を持つが，これはしか し $C_{2}$ の説明とは言いにくい，䟕ろ $G_{1}$ の修正と考えられる. $C_{2}$ の分子論的説明は依然として定説がないというのが実状であ る.

\section{5. 最近の 2 軸伸長実験の進歩}

$\partial W / \partial I_{i}$ の直接測定には， 2 軸伸長実験が必要であることは既 に述べたが，この実験には困難が伴う．2 軸に伸長することには 大きな問題はないが, その場合の精密な応力の測定に困難が生じ る. 更に, 変形の均等さの実現も問題の一つである. Rivlin が Fig. 1 のデータを得た当時は, 正方形のシート状試料の四辺の端 部を厚くし，これに等間隔に多数の系をかけて四方へ引っ張り， 系につけたばねばかりで張力を測定するという粗い方法がとられ ていた．今日からみると精度上に問題があったものと想像される。
しかし，この方法は最近までよく用いられ，例えばNBSのZapas が1960年代にこの方法を用い, BKZ 理論の補強を行っている ${ }^{16)}$. 一方, Ko と Blatz ${ }^{17)}$ はインストロン引張試験機 (1 軸引張) に 特別な装置を付加して 2 軸実験を試みているが，まだ基本的には Mooney 式に信頼を寄せていたようで，いわば 2 軸変形を応用し た一種の M-R プロットにこれを用いていた，これを Becker ${ }^{18)}$ が改良し，はじめてかなり精度の高いデータを得ることに成功し たのが 1965年頃で，そのデータは1967年に報告されたが， $\partial W /$ $\partial I_{1}$ も $\partial W / \partial I_{2}$ ともかなり複雑な関数形を持つことが指摘された. 精度を向上させた専用装置での測定が，筆者らによって始めら れたのは1966年頃からで，これによって弾性のみならず粘弾性挙 動や温度依存性の検討などが実施された。現在, 更に精度を向上 させた小変形域を対象とする装置も試作され, 両装置を併用して の測定が継続して行われている，そしていろいろの新しい事実が 明らかになってきたのであるが，次に述べるのもその一つである。

\section{Mooney-Rivlin プロットの再検討}

2 軸伸長実験によると, $\partial W / \partial I_{i}(i=1,2)$ の関数形が，その関 数形に何の仮定も設けずに決定できるのであるが，こうした実験 から求まったそれらデータが集まると，当然ながらこれまで沉用 されてきた 1 軸伸長実験のデータを，M-R プロットすることに より求めた $C_{1}$ や $C_{2}$ の值を改めて検討することができる。すなわ ち, その $C_{1}$ や $C_{2}$ が $\partial W / \partial I_{1}, \partial W / \partial I_{2}$ の值をそれぞれ正しく とらえているかどうかの点検が可能になる.

われわれが 2 軸伸長実験によって豊富なデータを得られるよう になって，まず行ったのはこの点検であった．結論はこれから述 べるように, M-R プロットの妥当性の否定である.

$\partial W / \partial I_{1}, \partial W / \partial I_{2}$ は，いずれも一般には $I_{1}$ と $I_{2}$ との関数とし
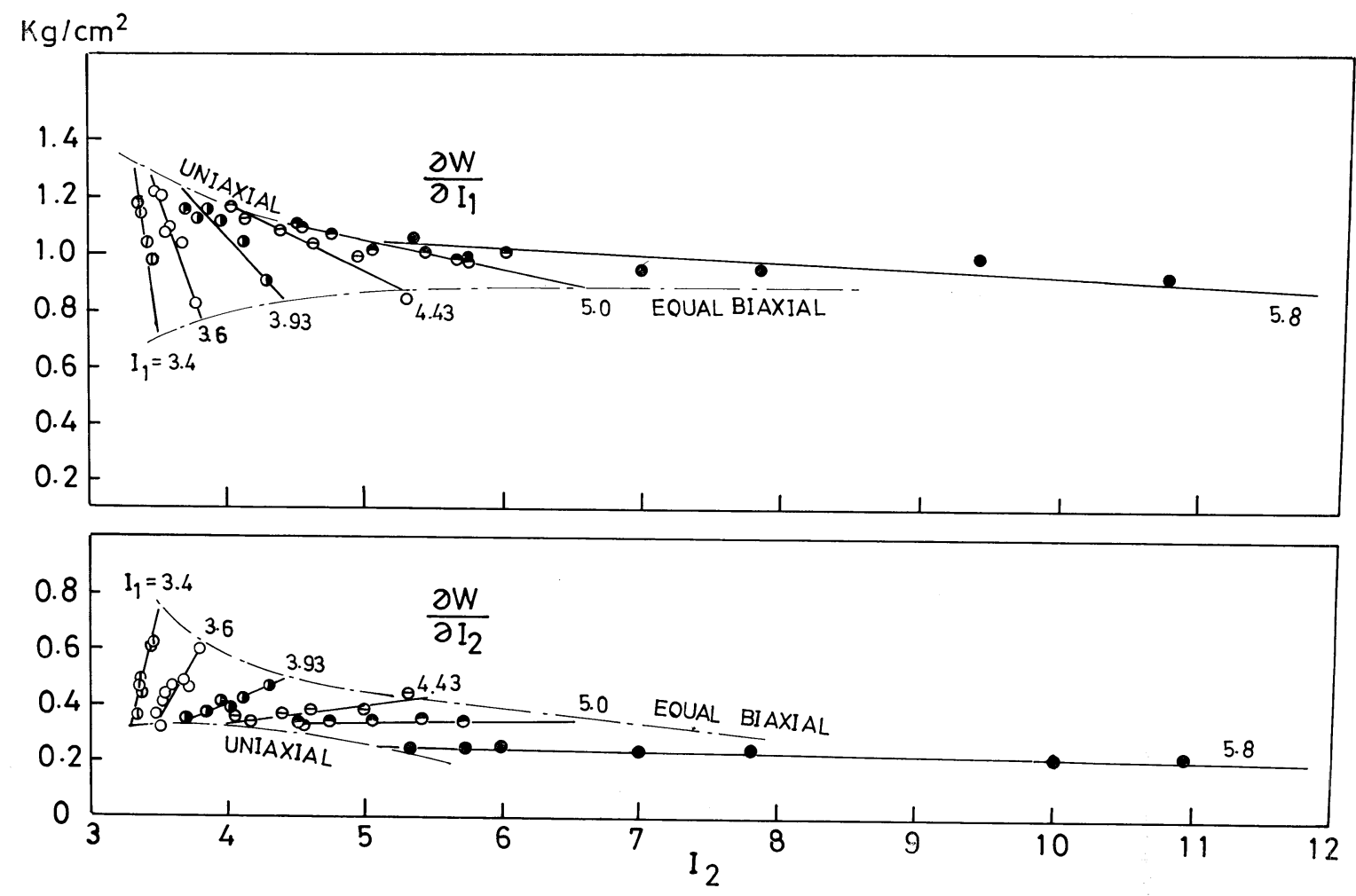

Fig. $2 \partial W / \partial I_{1}$ and $\partial W / \partial I_{2}$ for $\mathrm{SBR}$ vulcanizate (pure rubber) at $1 \mathrm{~min}$ and $22^{\circ} \mathrm{C}$. (Kawabata ${ }^{19)}$ ) 


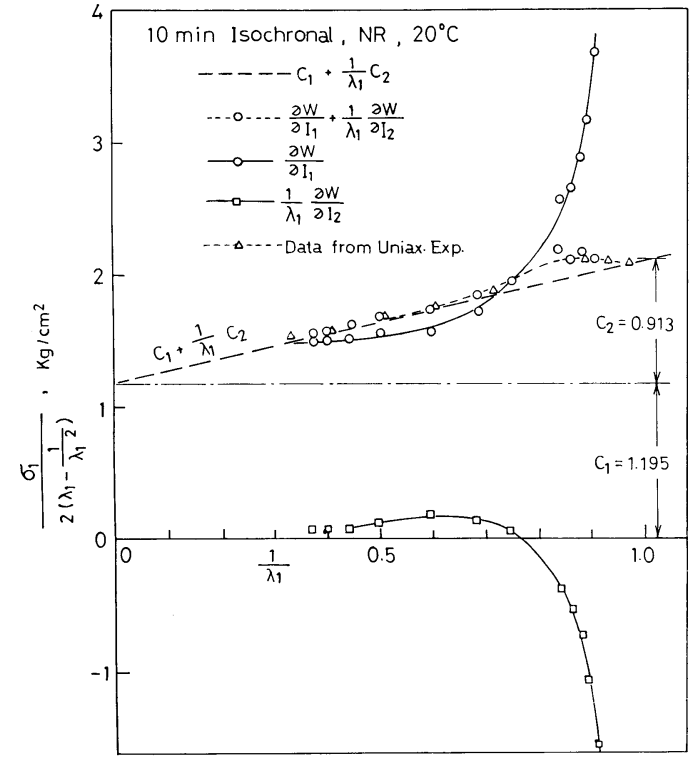

Fig. 3 Mooney-Rivlin plot for natural rubber vulcanizate (pure rubber) $(\triangle)$ compared with the sum of $\partial W / \partial I_{1}$ and $\left(\partial W / \partial I_{2}\right) / \lambda_{1}$ measured by extrapolation for uniaxial extension from biaxial data. $\left(\right.$ Kawabata ${ }^{20), 23)}$ )

て考えるべきであることは既に述べたが，2 軸実験の結果もこれ を明瞭に示している. Fig. 2 は，加硫 SBR（純ゴム）について のこれら 2 つの関数を $I_{1}$ をパラメーターとし， $I_{2}$ を変化させて 示している ${ }^{19), 20)}$. 変形の範囲は, 例えば $\lambda_{1}=1, \lambda_{2}=1.5$ の変形 は $I_{1}=I_{2}=3.69$ に対応する.このデータは 2 軸応力緩和実験から 求めた $1 \mathrm{~min}$ 等時データからとっている。 $\partial W / \partial I_{1}$ も $\partial W / \partial I_{2}$ も変形が小さくなるほど值の変化が急激になる傾向を持っている. 変形の大きい領域では $\partial W / \partial I_{1}$ はやや平坦になるが, $\partial W / \partial I_{2}$ は 減少を続ける傾向を持つ. この図で示される傾向や大体の関数形 は，NR など他の種類の加硫ゴムにも共通である. Mooney 式の

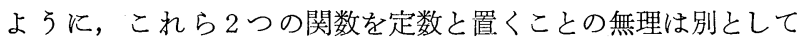
も，それよりも問題は $\mathrm{M}-\mathrm{R}$ プロットで得られる $C_{1}$ と $C_{2}$ とが, Fig. 2 に示される $\partial W / \partial I_{1}$ と $\partial W / \partial I_{2}$ との值と, 次に述べるよ うにそれぞれ大きくかけ離れた值をとることにある。

Fig. 3 に，加硫天然ゴム（NR，純ゴム）の M-R プロットを 示しているが20),23), $\triangle$ 印のプロットは 1 軸伸長特性からの通常の M-R プロットで, 伸長比 $\lambda_{1}$ が 3 程度までの範囲を示している。 太い点線で示しているょうに注㯰線となり，既に述べた方法で 縦軸との交点と傾斜とから，それぞれ $C_{1}=1.195 \mathrm{~kg} / \mathrm{cm}^{2}, C_{2}=$ $0.913 \mathrm{~kg} / \mathrm{cm}^{2}$ と読又取れる. ここで, 横軸 $1 / \lambda_{1}=1$ が変形前の 状態で, 変形の增加とともにプロット点は左方へ移動する. そし て, 約 3 倍程度の伸長比までは㘠に示すよ5にほぼ直線を示し, この後更に変形の大きい領域では直線は左上方に向って曲がり始 める傾向となる。 この傾向はいわゆる逆ランジュバン関数で近似 される非ガウス鎖理論の予想と一致するのであるが，この点につ いてはやや異なる問題となるので，ここでは触れない，通常， $C_{1}$ と $C_{2}$ はこの図のように直線部分から読み取られる.

一方， 2 軸伸長実験から 2 軸変形に対する $\partial W / \partial I_{1}, \partial W / \partial I_{2}$ の 值が直接に求まるが, 残念ながら 1 軸変形に刘してのそれらの值 は求まらない。これは，1軸变形様式では式(6)俚式(13)となり，2
つの未知数 $\partial W / \partial I_{1}$ と $\partial W / \partial I_{2}$ とを含んだ $1 つ の$ 方程式となる ので, これら未知数関して解けないからである. しかし, Fig. 2 に示したように，1軸变形状態に極めて近い変形様式要で 2 軸 変形様式の下で接近できるので, 外插によって1軸変形での值を 推定でき，それぞれを $\mathrm{M}-\mathrm{R}$ プロットで求まる $C_{1}$ と $C_{2}$ と比較 できる. Fig. 3 にこうして求めた $\partial W / \partial I_{1}$ と $\partial W / \partial I_{2}$ とを記入 しているが， $\partial W / \partial I_{2}$ そついて M-R プロットへの寄与がよく わかるよ5に $1 / \lambda_{1}$ を乗じた值で示している. 四から明らかなよ 5に，これら 2 つ值は定数とはならないことがすぐにわかるが， その絶対值に扣いても $C_{1}, C_{2}$ とはかなり異なった值をとること が明らかである。特に， $C_{2}$ の值は $\partial W / \partial I_{2}$ の值とは大きくかけ 離れている.ここで 2 軸伸長実験から求めた各 $\lambda_{1}$ に対する $\partial W /$ $\partial I_{1}$ と $\partial W / \partial I_{2}$ との值を, 次式

$$
\frac{\sigma_{1}}{2\left(\lambda_{1}-\frac{1}{\lambda_{1}^{2}}\right)}=\frac{\partial W}{\partial I_{1}}+\frac{1}{\lambda_{1}} \frac{\partial W}{\partial I_{2}}
$$

に $\lambda_{1}$ とともに代入し, 各 $\lambda_{1}$ に対する左辺の值を右辺から計算 して，M-R プロット図上にプロットするという，いわば逆コ一 スの M-R プロットを行ってみると ${ }^{20), 23), ~}$ 細い点線のようになる が，これは前述の 1 軸伸長データからの通常の M-R プロットの 結果と一致し，乙か子直線関係も得られる。これは 2 軸伸長実験 から得られるデータの精度上の正当さを示す一つの点検でもある が，それよりもこの事実は M-R プロットが直線を示したとして む, 必ずしもひずみエネルギー密度関数が Mooney の式, 式(11)に 一致するとは限らないこと，別の表現をすれば $\mathrm{M}-\mathrm{R}$ プロットか ら求まる $C_{1}$ と $C_{2}$ は, それぞれ $\partial W / \partial I_{1}$ と $\partial W / \partial I_{2}$ の值とは 必ずしも一致しないことを示している。すなわち， M-R プロッ トによって求めている值はひずみエネルギー密度関数とは異なる ことになる．

もら一つ, 更に別の例を示してみる. Fig. 4 は Fig. 2 と同じ 加硫 SBR 飞ついての同様の点検図であるが20),21)，2軸伸長実験 から求めた $\partial W / \partial I_{1}$ と $\left(1 / \lambda_{1}\right)\left(\partial W / \partial I_{2}\right)$ とを別にプロットし, それらの和，つまり 2 軸実験から求めた逆コースの M-R プロッ トを点線で示している。この点線はまた，1軸伸長実験からの通 常コースでの M-R プロットの結果とも一致していることは別に 確認している。図では $0.1,1,10 \mathrm{~min}$ の等時プロットを示して いるが，まず，前の例と同様に $\mathrm{M}-\mathrm{R}$ プロットから求まる $C_{1}$ と $C_{2}$ とはとれぞれ $\partial W / \partial I_{1}$ と $\partial W / \partial I_{2}$ との值と一致しないことは

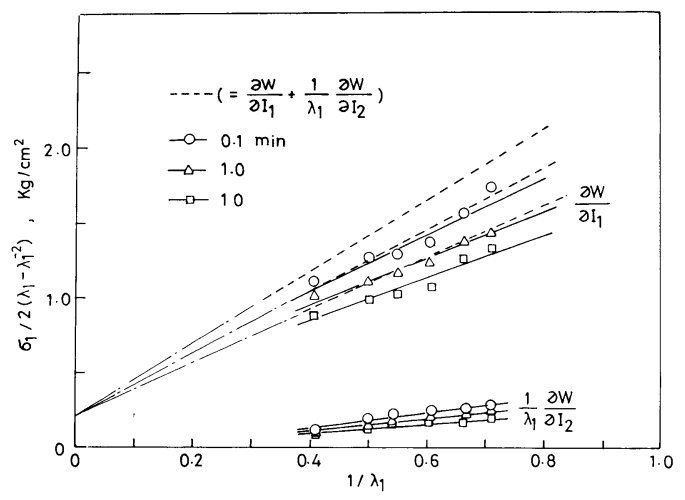

Fig. 4 Mooney-Rivlin plot from biaxial data shows time dependence of $C_{2}$, however it is shown that $\partial W /$ $\partial I_{1}$ is also dependent on time for SBR vulcanizate. 


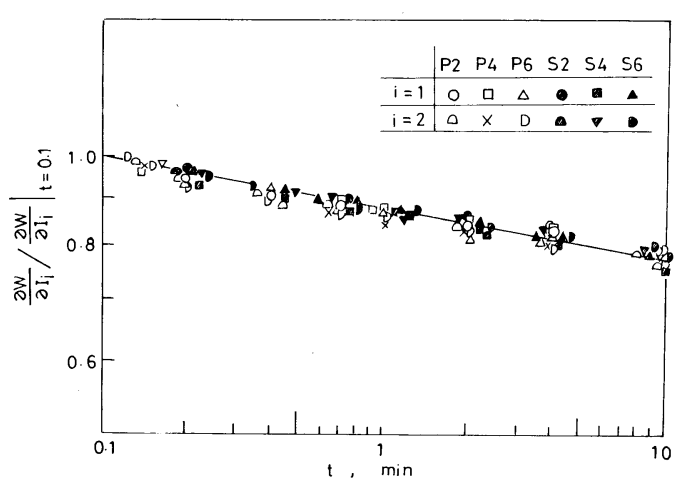

Fig. 5 Reduced time dependence of $\partial W / \partial I_{1}$ and $\partial W / \partial I_{2}$ for SBR vulcanizate at various deformations, $P_{2}$ $\left(I_{1}=3.935, I_{2}=3.777\right), P_{4}\left(I_{1}=4.002, I_{2}=3.908\right)$, $P_{6}\left(I_{1}=3.919, \quad I_{2}=4.292\right), \quad S_{2}\left(I_{1}=3.611, \quad I_{2}=\right.$ $3.611), \quad S_{4}\left(I_{1}=5.136, \quad I_{2}=5.142\right), \quad$ and $S_{6}\left(I_{1}=\right.$ $\left.6.519, I_{2}=6.606\right)$. (Kawabata, et al. ${ }^{19), 21)}$ )

明らかであるが，更に点線の延長を見るとあたかも縦軸上でこれ ら 3 つの直線が一致するよ5に見觉る。つまり $C_{1}$ の值は時間依 存性は持たず， $C_{2}$ のみ(つまり傾斜) が時間依存性を持つように 見える。つまり $\partial W / \partial I_{1}$ はレオロジー的举動を示さず， $\partial W / \partial I_{2}$ が顕著に示すという結果が導かれる。しかし, 図から明らかなよ らに，両者の等時プロットはいずれも同じレオロジー挙動を示 す. 事実, もっと詳しい 2 軸伸長実験から両者の緩和挙動を見る と, Fig. 5 に示すように ${ }^{19)}$ 両者の挙動はほぼ等しい.すなわち, Wが時間とともにスカラー的にェネルギー散逸し，これが応力の 緩和挙動をむたらすことをらかがわせる。しか子変形にも依存せ ず，次式の分離形が確認される ${ }^{19)} . \varphi(t)$ をスカラーの時間関数 として

$$
W\left(I_{1}, I_{2}, t\right)=\varphi(t) W\left(I_{1}, I_{2}\right)
$$

このことは, 加硫ゴムの大変形下でのレオロジー挙動をすこぶ る単純にし， 2 軸変形下での $\sigma_{1}$ と $\sigma_{2}$ との応力緩和举動は共通 の $\varphi(t)$ によって支配されることになり，かつ変形にもよらない ことを表している。.もちろん 1 軸変形での応力緩和举動も特別の 場合としては含まれ，共通である。式(17)の関係は通常の M-R プ ロットからでは全くわからない関係なのである。

\section{Mooney-Rivlin プロットが $\partial W / \partial I_{1}, \partial W / \partial I_{2}$ を正しく与えない理由について}

加硫ゴムでは一般に $\partial W / \partial I_{1}$ の值が $\partial W / \partial I_{2}$ に比べて大きい 值を持つが, 仮に両者のそれぞれの絶対值が同じ比率で変形依存 性を示すとすると，両者の和をとる $\mathrm{M}-\mathrm{R}$ プロットでは $\partial W / \partial I_{1}$ の絶対值の変化が和の值の絶対值変化量に大きく寄与する. 一方, $\mathrm{M}-\mathrm{R}$ プロットでは $\partial W / \partial I_{1}$ を定数と仮定して, この仮定から外 れる効果をすべて $C_{2}$ に負わせる結果となるので, 絶対值の大き い $\partial W / \partial I_{1}$ の変化が絶対值の小さい $C_{2}$ に流れこんで $C_{2}$ に加算 されるので，どうしても $C_{2}$ が過大に見積られることになりがち である.同じことが両者の時間依存性の関係㲹も現れる. 絶対值 の大きい $\partial W / \partial I_{1}$ の時間変化が， $\partial W / \partial I_{1}$ 自身が M-R プロッ ト上で傾斜を持っているので，あたかも $C_{2}$ の時間变化が顕著で あるように見せる. したがって，やや粗く直線を外插すると， Fig. 5 のよ5に各等時プロットと縦軸との交点が一点に集まると
いら結論に引き込まれるのである.

このように, $\partial W / \partial I_{1}$ がやはり変形とともに值を変える事実,

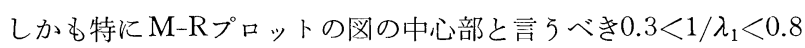
付近の領域, 伸長比 $\lambda_{1}$ では 1.2 3 程度の最も実験しやすい領 域で， $\partial W / \partial I_{1}$ がかなりその值を変えるという事実が大きく $\mathrm{M}-\mathrm{R}$ プロットに影響するのである. しかもその变化が Fig. 2 からわか るよ 5 に双曲線的，または指数関数的であって，ちょうど $1 / \lambda_{1}$ と直線関係を持つところに落とし穴があるように感じられる。

\section{8. これからの問題}

ひずみエネルギー密度関数の関数形に関しての知見が，近年少 しづつ観測によって得られ始めている。例光ば，Fig. 6 は $\partial W /$ $\partial I_{1}$ と $\partial W / \partial I_{2}$ の温度依存性に関する加硫天然ゴムについてのデ 一タである20),22)。前者は明らかに温度依存性を示し，しかも絶 対温度に比例している. しかし, 後者は温度に不感性を持つ. こ の結果は既に述べた時間依存性とは対照的である。しかし，M-R プロットからはとさにはこれと反転した結果が得られたりまた それに基づいて状態方程式を導く試みがなされたりするなど混乱 していたが，こうした混乱はやはり M-R プロットの持つ危険性 に原因していたように思われる。Wの高次展開式の高次項を用い て，いかに M-R プロットの適合性を追求しても，1軸伸長実験 からのみの情報に基づいている限り，筆者には無䭾な努力のよう に思われる，例えば，適合性の良い関数形を求め元ても，それは 必ずしも $\partial W / \partial I_{1}$ や $\partial W / \partial I_{2}$ の関数形を正しくとらえていると いう保証はない，それは，そうして求めたこれらの值を用いて2 軸伸長挙動の予測を試みても, 恐らく大きな誤差を持つことから も実証されよ5。したがって，これらのデータを分子諭的研究の 拠り所とするには細心の注意が必要となろう。

$\partial W / \partial I_{1}$ に相当する量が定数として, 古典ゴム弾性論から式(9) (i)のように, 分子諭的に誘導されるが，それが定数であること の当否は別にして，Fig. 6 の結果を見てわかるように，この誘導 は基本的に妥当なように思われる。しかし， $\partial W / \partial I_{2}$ については その関数形が正確につかめ出せたのは比較的最近のことで, もち

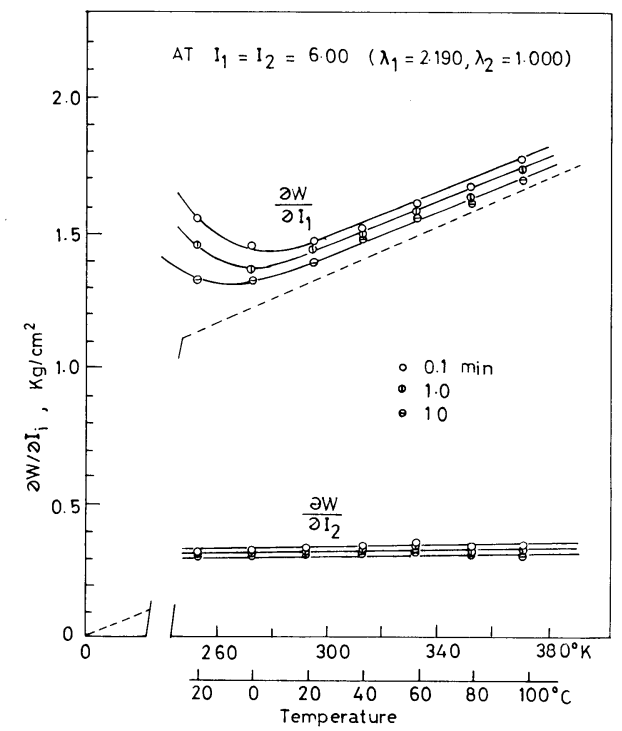

Fig. 6 Temperature dependence of $\partial W / \partial I_{1}$ and $\partial W / \partial I_{2}$ for the NR. (Kawabata ${ }^{19), 23)}$ ) 
ろんこれについての分子論的な説明についての定説は確立してい ない，筆者らはこれについて分子間力が関与するエネルギーから もたらされるとの見方を強めているが，もちろんこの点の解明に は今後のもっと豊富な実測值の集積が必要であり，これからの興 味あるテーマの一つになっている。

\section{文}

\section{献}

1) Meyer, K.H., von Susich, G., and Valko, E., Kolloid-Z, 59, 208 (1932).

2) Guth, E. and Mark, H., Mh. Chem., 65, 93 (1934).

3) Kuhn, W., Kolloid-Z., 68, 2 (1934).

4) James, H.M. and Guth, E., J. Chem. Phys., 11, 455 (1943).

5) Treloar, L.R.G., Trans. Faraday Soc., 39, 36 (1943).

6) Flory, P.J. and Rehner, J., J. Chem. Phys., 11, 512 (1943).

7) Mooney, M., J. Appl. Phys., 11, 582 (1940).

8) Rivlin, R.S., J. Appl. Phys., 18, 837 (1947).

9) Rivlin, R.S., Phil. Trans. Roy. Soc., A241, 379 (1948)

10) Rivlin, R.S., ibid., A242, 173 (1949).

11) Rivlin, R.S., Proc. Roy. Soc., A195, 463 (1949).
12) Rivlin, R.S. and Saunders, D.W., Phil. Trans. Roy. Soc., A243, 251 (1951).

13) Rivlin, R.S. and Thomas, A.G., Phil. Trans. Roy. Soc., A243, 289 (1951).

14）例えば, Eringen, A.C., “Nonlinear theory of continuous media”, (1962) McGraw-Hill, New York.

15） 1)〜8）のほか, 例えば Treloar, L.R.G., “Physics of rubber elasticity", (1958) Clarendon Press, Oxford.

16) Zapas, L., J. Res. Nat'l Bur. Std., 8-A, 525 (1966).

17) Blatz, P.J. and Ko, W.L., Trans. Soc. Rheol., 6, 223 (1962).

18) Becker, G.W., J. Polymer Sci., C-16, 2893 (1967).

19) Kawabata, S., J. Macromol. Sci.-Phys., A2, 7, 635 (1969).

20) Kawabata, S. and Kawai, H., Adv. Polymer Sci., 24, 89 (1977) Springer-Verlag, Berlin, Heidelberg.

21）浫原法, 川端季雄, 河合弘廸, 材料, 19, 317 (1970).

22) Kawabata, S. and Akagi, T., Proc. 16th Japan Congr. Materials Sci., 1973, 253 (1973).

23）川端季雄，第25回高分子学会年次大会予稿集， 25-2，416 (1976). 